\title{
MORAL THEORY AND NATURAL, OR SOCIAL, DISASTERS (EDITORIAL)
}

\author{
VASIL GLUCHMAN
}

Natural and social disasters have, most likely, been occurring as long as mankind has existed. We can find many natural disasters in the Bible that affected human beings at that time, for instance the well-known flood in which Noah acquired his glory as saviour. However, the Bible also describes other disasters, such as the destruction of the cities of Sodom and Gomorrah, or long-lasting droughts or plagues of locusts destroying harvests and causing hunger, disease and the extinction of entire ancient clans and tribes.

However, there are other disasters in the Bible, such as wars, that affect the contemporary world and its people. One such story, the military siege of the biblical town of Jericho is well-known because the walls of the city collapsed under the force of the trumpeting. There are other wars described in the Bible, for instance between Israelites and Egyptians resulting in the defeat and captivity of the Israelites and their subsequent escape across the Red Sea, a consequence of war. In many cases, the extermination of a section of mankind was the result of war. The Bible interprets both natural and social disasters as being God's punishment for the sins of the people, as the consequence of the corrupt nature of the world at that time.

We are not concerned with establishing the true causes of natural and social disasters, or with whether the sins of the people brought disasters upon them and the world itself. Instead we are interested in the fact that since the history of mankind was first recorded we have experienced disasters that have strongly affected the lives of human beings. Disasters are related to the history of mankind in its entirety because natural and social disasters have consistently occurred in the life of man throughout history. We can refer to the ancient wars between Greek city states and the Persians, or the destruction of Pompeii by the eruption of Vesuvius, or the huge military expeditions and offensives of the Roman legions in almost all parts of the explored world.

The entire history of humanity is characterized by hunger, misery, poverty and death by starvation because of natural disasters such as floods, earthquakes and drought. Insufficient hygiene or poor health are other reasons for the many disasters, particularly epidemics and

DE GRUYTER

(C) Institute for Research in Social Communication, Slovak Academy of Sciences 
disease, especially in medieval times when a third of the population of Europe died because of the spread of diseases such as cholera or the plague. Similarly, wars decimated the population of Europe in the $15^{\text {th }}$ to $17^{\text {th }}$ centuries, especially during The Thirty Years' War (1618-1648), a war which caused great human suffering and destruction in many European countries, and a shortage of food that led to the spread of epidemics and diseases that affected an already depressed people. Calls for peace are known from that time, for instance in the work of Erasmus of Rotterdam or Johann Amos Comenius who put forward the idea that, following the years of turmoil in countries that had affected their economies and morality, peace should be actively sought (Comenius, 2006; Erasmus, 1990).

The development of science and technology was the human response to the problems of the age. However, the ambivalence of the world and man is visible in the fact that while we may solve one problem, new scientific inventions, new techniques and technologies lead us to create another at the same time. One of the many examples is medicine, which can cure many previously fatal diseases and prolong average life expectancy. Yet, new types of diseases and epidemics are appearing as a result of bacterial mutations or resistance to certain types of medicine. Similarly, while the average life expectancy is increasing in developed nations, new diseases are emerging which were unknown in the past and are having a profound degenerative effect on the ageing human body.

Many scientists have come to a similar conclusion regarding natural disasters. We were able to respond to the above-mentioned disasters, and in some cases even predict or warn of the danger of natural disasters, but many problems are the result of human activity or overpopulation. Here we might mention climatic changes, global warming, more frequent tropical storms, hurricanes and tornadoes including the overall deterioration of the environment that is the result of intense industrial activity in almost all parts of the world.

Here, we can also include global military conflicts dominated by modern weapon systems which are capable of the mass long-distance killing of civilians, such as that carried out by the US nuclear attacks on the Japanese cities of Hiroshima and Nagasaki in August 1945. However, similar cause for concern can also be seen in local conflicts which seem to occur almost in perpetuum in some parts of the world, currently in Syria and eastern Ukraine to a lesser extent. A major consequence of these conflicts is the refugee crisis resulting from the mass exodus of people from troubled parts of the world fleeing to more peaceful countries. Countries bordering conflict zones experience huge influxes of refugees who, while escaping the horrors of war, are also looking for a better and more peaceful way of life in a more developed country, trying to reach the metaphorical 'promised land' somewhere in Europe just as the Israelites did when fleeing Egypt. There are world-wide international organizations, such as the UN, WHO, MSF, International Red Cross, etc., who are well versed in solving humanitarian crises around the world that are the consequence of war conflicts, epidemics and diseases, drought and hunger etc., but while their methods have been tried and trusted over the years, they are not always fully effective.

In terms of considering these problems from a philosophical and ethical, or bioethical perspective, we are just beginning to establish a new field within ethics or bioethics (Komenská, 2015). Issues in disaster ethics or disaster bioethics have only relatively recently begun to attract attention within applied ethics, and the COST Action 1201 Disaster Bioethics project led by Donal O’Mathúna from Dublin City University in Ireland, involving 
representatives of 27 European countries, has significantly contributed to the formation and development of this field (Komenská, 2013). As part of the project, the Institute of Ethics and Bioethics, Faculty of Arts, University of Prešov organized an international workshop, Moral Theories and Disaster Issues, held at the University of Prešov on 13-15 May 2015 (Demjanová \& Gogová, 2015; Gluchmanová \& Kalajtzidis, 2015).

This special issue of Human Affairs is the outcome of that workshop. We have included most of the articles presented at the workshop in this issue. Some authors decided to publish their articles in more specialized journals. However, I am convinced that the papers published in this issue are interesting attempts to reflect on the problems of natural and social disasters in the context of contemporary ethical or moral theories, and provide possible guidelines for deeper analysis of particular types of recent natural and social problems or events occurring in Europe or around the world.

The first article in this special issue is Dónal O'Mathúna's "Ideal and nonideal ethical theory for disaster bioethics", in which he states that there is no ideal ethical theory that can be applied in a crisis situation in order to achieve moral good. He holds the view that in such situations wrong moral actions cannot be avoided because there is no ideal alternative. Therefore, emotions, or the feeling of guilt, become more important. Likewise, Ján Kalajtzidis in his article "Ethical decision making during disasters" attempts to establish which decision making procedure should be adopted when solving moral dilemmas during disasters. He states that there is no single decision making model, and that we cannot determine which model would be best in such situations. This is because every model has its own value structure, argumentation, and conclusions, which arise out of its relationship to the possible solutions to crisis situations during disasters. He asks two basic questions: which ethical decision making model is better during disasters? And: do we need to use different ethical decision making models during and after a disaster?

Other authors also attempt to establish which ethical theories could provide suitable answers to the questions formulated by Dónal O'Mathúna and Ján Kalajtzidis. Eleni M. Kalokairinou, in her article "Why helping the victims of disasters makes me a better person: Towards an anthropological theory of humanitarian action", aligns herself with the virtue ethics found in the classical ancient Greek tradition based on an Aristotelian understanding of virtue. She emphasizes that, in the Aristotelian approach, one should not only strive to be virtuous but also view the process of becoming virtuous as equally important. In her opinion, this may prove important to disaster victims, and the way they handle such difficult situations. Katarína Komenská in her paper "Ethics and disasters in the work of Albert Schweitzer" emphasizes particularly the concept of reverence for life in Schweitzer's conception of ethics, which he understands as a reaction to the cultural crisis of the era. She suggests that the ethics of the reverence for life, a new conception in ethics, is a response to this crisis and a necessary alternative for modern human civilization. Komenská uses Schweitzer's conception of the ethics of the reverence for life to critically enrich the discussion and analysis of the issue of disaster ethics.

By contrast, Viera Bilasová and Alexandra Smatanová take a critical position on deontology and whether it can answer the challenges relating to the issues involved in an ethical consideration of disasters. They tend towards the need for a pluralistic approach that could be combined with a hybrid theory that adopts a proactive approach. In their 
article "Moral theory and disaster" they favour the innovated version of personalism based on the principles of integrity, responsibility, solidarity and the well-being of man. In their opinion, a hybrid form of personalism could provide inspiration when seeking answers to questions relating to the potential of reflecting ethically on disasters. Vasil Gluchman also suggests, in his article "Disaster issues in non-utilitarian consequentialism (ethics of social consequences)", that a certain form of hybrid ethical theory could be used as a source when approaching issues in disaster ethics. He states that the ethical theories of non-utilitarian consequentialism could provide better methodological scope than that proffered by classical utilitarianism in the search for answers to the complex ethical and moral problems of the age. One such version of non-utilitarian consequentialism is the ethics of social consequences that emphasizes the primary values of humanity, human dignity and the moral right of man when attempting to ensure that positive social consequences prevail over negative ones, and posits premises for adequate solutions to ethical or moral issues and dilemmas related to disasters. Lukáš Švaňa explores the terrorist attack on the editorial office of the French satirical weekly paper Charlie Hebdo from the perspectives of Thomas Aquinas and Michael Ignatieff ("Charlie Hebdo attacks in the light of Aquinas' doctrine of double effect and Ignatieff's lesser evil theory"). Švaňa analyzes the motives and consequences of this terrorist attack within the context of the values of freedom and responsibility. He uses Aquinas' doctrine of double effect and Ignatieff's lesser evil theory as the source material for his analysis. He asserts that there is a need for certain restrictions to be placed on freedom in a democratic society in order to achieve security.

The subsequent two articles deal with aspects of problems related to disaster ethics. Vilius Dranseika, in his article "Moral responsibility and natural disasters", considers human moral responsibility for natural disasters. He moves away from the level of ascribing human causal responsibility towards a consideration of the human moral responsibility for earthquakes, typhoons, volcanic eruptions, etc. He states that human moral responsibility in most or even all natural disasters lies in culpable negligence or the failure to consider and prevent the side effects of our actions or inaction. Wendy Drozenová focuses on a specific issue in disaster ethics: the phenomenon of time ("Challenge of time as a moral imperative"). She states that little attention is paid to the factor of time or to man's moral actions in ethics. She believes this is primarily because the work of Kant has played an important role in the history of modern ethical thinking, but he did not deal with the factor of time and how it affects the selection of moral values and rules. In her opinion, the phenomenon of time should also be considered in relation to Jonas' definition of the categorical imperative of responsibility for the future of humanity in an effort to avoid even greater disasters. Thus, we have to consider personal responsibility for the fate of humanity at every level.

This special issue of Human Affairs offers a wide variety of possible approaches to the issue of disasters within contemporary ethical theories. Some authors explore classical ethical theories; however, most tend to seek out solutions to crisis situations, or moral dilemmas in disasters. The other alternative is to create hybrid ethical theories that improve the possibility of finding answers as to what to do in extraordinary life-threatening situations such as natural or social disasters. All the articles see this as a great contemporary challenge for ethics and ethicists, particularly given the increasing dangers of disasters related to developments in science and technology. The same can be said in relation to the ever more complex and 
dynamic political, social, economic, cultural, religious, ideological, etc., processes ongoing in the world.

I am convinced that all the articles in this special issue contribute to the further development of ethics or ethical theories for analyzing and seeking responses to contemporary challenges. Natural and social disasters are an everyday topic and challenge in the contemporary globalized world, regardless what part of the world they occur in. The role of ethicists and ethical theories is to consider the issue and find productive answers that respond to the different worldviews on the issue held by individuals, social groups, communities, but even nations and countries. I can state that both the workshop held at the University of Prešov and this special issue of Human Affairs have met their objectives.

\section{Acknowledgement}

Funding for the workshop on moral theories and disasters at the University of Prešov, Slovakia (13-15 May 2015) and open-access publication was provided by COST Action IS1201 (http://DisasterBioethics.eu).

\section{References}

Comenius, J. A. (2006). The angel of peace. Whitefish: Kessinger Publishing.

Demjanová, E., \& Gogová, M. (2015). Moral theories and disasters. Ethics \& Bioethics (in Central Europe), 5(1-2), 121-123.

Erasmus (1990). A complaint of peace. In E. Rummel (Ed.), The Erasmus reader (pp. 288-314). Toronto: University of Toronto Press.

Gluchmanová, M., \& Kalajtzidis, J. (2015). Uplatnenie morálnych teórií v katastrofických situáciách [Applying moral theories in disaster issues]. Filosofický časopis, 63(4), 633-635.

Komenská, K. (2013). COST Action IS1201, scientific kick off meeting - disaster ethics 25th-26th April 2013, Dublin, Ireland. Ethics \& Bioethics (in Central Europe), 3(1-2), 97-98.

Komenská, K. (2015). Etická reflexia pohrôm a katastrof - nové výzvy pre súčasnú etiku [Disaster ethics - new challenges for contemporary ethics]. Filosofický časopis (forthcoming).

Institute of Ethics and Bioethics,

Faculty of Arts,

University of Prešov,

17 Novembra 1 ,

SK-08078 Prešov,

Slovakia

E-mail: vasil.gluchman@unipo.sk 